\title{
Decentralization and Democratic Local Government in Cross River State, Nigeria: A Fact or Fallacy
}

\author{
Ikeji, C. C; Utulu, Paul.B; Ojah,Okpo; Akpan, Emmaunuel I; Ibah, Joseph \\ Institution of Public Policy \& Administration University of Calabar.
}

\begin{abstract}
This study focused on decentralization and democratic local government in Cross River State, Nigeria. Sample size of 900 was adopted for the purpose of the study. Stratified random sampling was used in the study. Stratification was done on the basis of geopolitical zone, political party affiliation and educational status of the respondents. 900 political party members evenly distributed (300 apiece) among the three leading political parties in the last general elections were used as respondents for the purpose of the study. Each respondent has at least an SSCE/WASC educational qualification. 300 respondents were interviewed in each of the geopolitical zones (i.e. South, Central and North). One hypothesis was tested. Results showed the political class themselves perceive the local government administration system in Cross River State as not effective and developmentfocused based on the provisions of the constitution of the federal republic of Nigeria.
\end{abstract}

Keywords: Decentralization, Democratic, Fact, Fallacy, Local Government

\section{Introduction}

According to Abutudu (2011), governance at the grassroots in Nigeria is in a state of crisis. This crisis stems from what increasingly looks like deliberate efforts to stem the advance of democratic governance at the local government level in the country. As a tier, the local government retains its outward appearance. It even goes through the motions of performing its functions. However, the crisis into which it is enmeshed has undermined its essence as government whose authority is directly derived and anchored in the Constitution.

Section 7 (1) of the 1999 Constitution specifically provides: "The local government by democratically elected government councils is under this Constitution guaranteed". The section went on to enjoin state governments to give content to this provision through enactment of enabling laws. According to the constitution of Nigeria, the only form of governance under which the local government must be run as a democratic one. There has been a conscious andsystematic degradation of this constitutional provision on democratic governance, and this constitutes thecentral problem of the local government system in Nigeria today. Democracy seeks to anchor government on the people. The principal means of doing this is elections. Elections, in a simple sense, enables a people to choose those who will govern them. In enabling 'government', elections, as the chief tool to midwife a democracy, also implies that those given the mandate to govern must view that mandate in terms of the imperative of promoting the welfare of the electorate. Equally, those who have been given the mandate to govern must be responsible andaccountable to those who gave them the mandate; that is, the electorate. In effect, 'development' and 'good governance' are key concepts that have become increasingly intertwined with democracy. Denied of its anchor on ademocratic base, the local government system in Nigeria is invariably suspended from the grassroots. The local councils can hardly be developmental, just as they are practically unaccountable. They are in fact imposed structures that have increasingly become sad and forceful reminders of the systematic disempowerment that has become the lot of the grassroots in Nigeria (Abutudu, 2011; Ikeji, 2002; Ikeji, 2006).

\section{Problem Statement}

The need for an effective and development-focused local government administration system in Nigeria in real terms is a problem and challenge that most states of Nigeria have not been able to solve. It is generally believed that a representative and effective local government administration will in turn lead to development at the grassroots level bearing in mind that local government system is the closest level (tier) of government to the people (Abutudu, 2011). It is pertinent to spell out pointedly that the beauty of 'Decentralization' (the principle upon which the system of local government is based) is arguably in the mobilization of the local resources and people with good knowledge of their local needs for effective grassroots transformation. This is in line with the philosophy of grassroots participation and 'bottom-top' approach to development pursuits. However, this goal and hope as captured in the Constitution of the Federal Republic of Nigeria has generally remained a mirage since the inception of the present democratic dispensation in Nigeria in 1999. This problem has been reported in other studies (Ikeji, 2002; Ikeji, 2006; Abutudu,2011;Mukoro, 2009;Green, 1995; Wunsch and Olowu, 1990; Olowu and Erero, 1997). The local governments in Nigeria are generally believed to be non-independent, nonautonomous, foisted (forced) on the people by the political elites, and therefore unaccountable and inefficient in the performance of their democratic and political duties. The general feeling is that an effective local government 
system, that is, one which involves the local population in decision making and provides for public accountability, is generally absent in Cross River State.

\section{Objective of the Study}

The objectives of this study are:

1. To ascertain whether or not there is interference by the state government in the affairs of the local governments in Cross River State.

2. To assess the effect(s) of the interference on the goal-attainment capacity of the local governments in Cross River State.

3. To ascertain whether local government, so properly defined, exist in reality in Cross River State.

4. To identify the means or medium by which the interference is conducted

\section{Research Question}

1. To what extent has the goal of 'Decentralization' envisaged by the Nigerian Constitution been attained through the instrumentality of Local Government System in Cross River State?

2. What factors undermine the realization of the provision of the Nigerian Constitution regarding the goal of instituting a truly local government system in Cross River State?

\section{Statement of Hypothesis}

The following hypothesis which serves as basis for this study is hereby stated in alternate form:

1. Involvement by the state government in the affairs of the local governments has significantly undermined the capacity of the local governments to function well

\section{Literature Review}

The concept of Local Government may be seen as "a segment of a constituent state or region of a nation state", established by law to provide public services and regulate public affairs within the area of its jurisdiction (Ikelegbe, 2005: 38-9). Although the lowest level of government (and therefore, closest governmental authority to the people), it is supposed to possess the necessary powers to function and control its own finances and personnel. Although territorially and functionally demarcated as a constituent unit of a larger and higher level of government to which it is responsible, it must also have some level of autonomy which is commensurate with its functions, local peculiarities and democratic credibility. "It is government under the responsibility of the local people and in the interest of the local population by local representative bodies" (Ikelegba, 2005: 39). As King observed, the local government is universally found in modern polities, although it goes by various appellations. Its legitimacy lies in its "claim to represent the interests or wishes of the local inhabitants and to administer to their needs". Founded on democratic ideals, it is required "that they be given an opportunity to control their affairs at this level, especially since this is the point at which their interests and welfare are most likely to be directly affected" (King: 1988; 3).

According to Wunsch (2001), African states, since the early 1980s, have expended much rhetoric and, in some cases, substantial resources on political and administrative decentralization, expressed in terms of local governance (genuine local autonomy and control over important services and investments). These reforms involve significant changes in planning, budgeting, personnel, expenditure and service functions. They range from very substantial efforts, as in post-1985 Uganda, Botswana and Nigeria in the early 1990s, to more limited efforts as in Ghana, Kenya and Tanzania (Olowu, 2001). To achieve functioning local governance systems each country has had to wrestle with the legal and administrative details involved in this substantial politicaladministrative reform (Olowu and Smoke, 1992).

Mukoro (2009) tells us that the desire to strengthen local government and thus make it a veritable organ for development has a long history around the world. Its philosophic roots can be traced to the works of Rousseau and that of Alexis DeTouqueville. Rousseau's works focused on the discussion on how government ought to be set up and run if they are to be good government, that is, when the reason for government is aimed for the common good and is wholly supported by all citizens of good will (Thomson, 1968). Rousseau's ideal state is a very small, compact, more like the tiny Greek states of old. Alexis DeTouqueville (1969), on the other hand was fascinated by the nature of America's democracy and public administration. This arose from his visit to the UnitedState of America (U.S.A.) and the realization that the citizens were very much involved in the management of their government whether at the local, municipal or at the metropolitan levels.

History abound within the African continent to prove that organized state structures existed in most parts of Africa hundreds of years before its social structure was laid waste by slavery and colonialism according to Johnston (1998). These states, under hereditary monarchies, were characterized by complex institutions such as age-based military conscription, taxation, advisory structures, an education system, a judicial system, markets 
and so on (Mukoro, 2009). The experience of many African countries with the style of adopting the system of government inherited from their colonial masters has often turned out to be a failure(Green, 1995; Wunsch and Olowu, 1990). Several reasonsaccount for the failure, ranging from a combination of uninhibited particularism with fallouts such as corruption, incapacity to resolve social conflict peacefully, external pressure and intervention, rapid technological outclassing and economic incompetence. In the view of Johnston (1998), this has led 'since the late 1970's to declining legitimacy on the part of the African state and its institutions in some countries. This has in turn led to the marginalization of the state and in some cases its collapse'. In the Nigeriancontext, it has been argued that the formal structures ofgovernment in Nigeria have increasingly become a fictionin governance. According to Olowu and Erero (1997), the services they provide have declined sharply in quality and quantity, which inadvertently has given rise to the development of alternative institutional structures for providing essential services.

Considered from another dimension, empirical studies have shown that highly centralized states are expensive to run, they are cumbersome, inflexible and are subjected to being abused (Esman, 1991). Similarly, it has been argued that democracy must be rooted in functioning local, participatory self-governance institutions (Wunsch, 2004). Democracy has certainly shown itself to be the best system for controlling governments and engaging people in their own governance. The position of several literatures on governance is in no doubt unanimous that African governments have not been doing well politically and economically. They are therefore of the belief that emphasis should now be shifted to the growth of civil societies, public ownership of political institutions, mobilization of talents and resources into constructive patterns and countervailing power vis-à-vis national institutions.

This new re-awakening is undoubtedly a reaction to years of frustrating experience with highly centralized national governments. A very ready explanation that can be given for the continuing malaise of governance in African nations is the choice of their policies and the strategies employed in pursuing them. These policies include centralization (Olowu, 1995), central control of resources both fiscal and jurisdictional (Gboyega, 2003; Skelcher, 2005; Mutahaba,1989), turbulent economic and policy environment which have undermined local institutions (Olowu and Wunsch, 1995, 1996), leadership attitude to the laws of the land as if they are unchangeable and the absence of complimentary reforms in the legal systems (Ayee, 1997). According to Wunsch (2004), the underdeveloped local civil society left local governments rudderless as they tried to develop policy and deliver services.

\section{Theoretical Framework}

The Institutional theory is used for the purpose of this study. Two defining elements are shared by the theoretical approaches to institutionalization in organizations (most explicit in Zucker 1977:728): (a) a rule-like, social fact quality of an organized pattern of action (exterior), and (b) an embedding in formal structures, such as formal aspects of organizations that are not tied to particular actors or situations (non-personal objective). The Concept of Environment as institution was proposed by Thomas \& Meyer (1984). Institutional environments obtain their defining power from "rationalization" and from accompanying state elaboration. These environments are constructed as one consequence of a much wider "state project," related to expansion of state jurisdiction (Thomas \& Meyer1984:469). This "statist" view conceives of the collective normative order, including the professions and widespread agreements shared by members of organizational fields, as linked to a broad conception of the state (Thomas et.al., 1987; DiMaggio \&Powell, 1983). Conformity of organizations to the collective normative order increases the flow of societal resources and enhances "long-run survival prospects" (Meyer \& Rowan 1977:252).Institutional elements invariably come from outside the organization. When organizations respond to external institutional pressure (or possibly only to coercive pressure as in DiMaggio \& Powell 1983), they protect their technical activities through decoupling elements of structure from other activities and from each other, thus reducing their efficiency (Meyer \& Rowan 1977:357, Weick 1976, Selznick 1949). In contrast, in line with predictions from economic theory, firms that operate in the technical sector "succeed to the extent that they develop efficient production activities and effective coordination structures" (Scott \& Meyer 1983:141). But efficiency and success do not necessarily covary in institutional theory: Organizational conformity to the institutional environment simultaneously increases positive evaluation, resource flows, and therefore survival chances, and reduces efficiency. In this view, the social becomes mythical and implicitly dysfunctional in strict task performance terms, while the technical remains real and rational (Meyer \& Rowan 1977:356-57). Institutionalized organizations serve many important legitimating functions, but the core tasks are not performed as well as they would be in a market-oriented organization, and basic organizational objectives are also often deflected (Selznick 1957, reviewed in Perrow1986:159-64).

In the context of this study, the Local Government Administration is the organization while the environment is the undue and unconstitutional influence of the state government as reported by previous scholars (Abutudu, 2011; Ikeji, 2002; Ikeji, 2006; Mukoro, 2009; Green, 1995; Wunsch and Olowu, 1990; Olowu and 
Erero, 1997). According to Meyer and Rowan's (1977) argument, the conformity of the local government administration to the state government increases the flow of resources from the latter to the former and enhances the former's (i.e. local-government-level politicians) long run survival prospects in political arena. The direction of the local government administration's carrying out of its duties invariably comes from the outside (the state government). This in turn leads to inefficiency or dysfunctionalism, as suggested by Meyer and Rowan (1977).

\section{Research Methodology}

Study Area

Cross River State, Nigeria is the study area for the purpose of this study. Cross River State is divided into 3 geopolitical zones: South, Central and North. The three geopolitical zones formed study area of the study.

\section{Sample Size}

Sample size of 900 is used for the purpose of this study. 300 respondents were interviewed in each of the 3 geopolitical zones. 100 party members of each of the three leading political parties (People's Democratic Party (PDP), All Nigeria People's Party (ANPP), and Action Congress (AC)) were interviewed in each of the three geopolitical zones. These formed the 300 per geopolitical zone and 900 for the 3 geopolitical zones making up the state.

\section{Sampling Technique}

Stratified random sampling was used for the purpose of this study. One level of stratification was done based on the location (i.e. the 3 geopolitical zones for the purpose of attaining 300 respondents per zone), another level of stratification is done to ensure that respondents with at least SSCE/WASC educational qualification are the ones used for the purpose of this study. Then, Simple Random Sampling was done to give every person equal chances of being selected for the survey, this is for the purpose of reducing 'bias' to the barest minimum, and getting a sample that is a fair representation of the population of the political class.

\section{Data Collection Procedure}

Data collection was done by the administration of questionnaire to every respondent interviewed for the purpose of the study. 900 questionnaires were administered and retrieved for the purpose of the study.

\section{Analytical Procedure}

One-sample T-test is used for the purpose of this study. One-sample T-test is used because it is conventionally accepted as a tool for making deductive inference based on observation of data.

\section{Results and Discussion}

Results

Test of Hypothesis:

Table 1: Summary Statistics on Capacity of Local Governments

\begin{tabular}{|l|l|l|l|l|}
\hline & $\mathrm{N}$ & Mean & Std. Deviation & Std. Error Mean \\
\hline $\begin{array}{l}\text { Capacity of } \\
\text { Governments }\end{array}$ & Local 900 & 1.2400 & .29589 & .00986 \\
\hline
\end{tabular}

Table 2: One-Sample Test on Capacity of Local Governments

\begin{tabular}{|c|c|c|c|c|c|c|}
\hline & \multicolumn{6}{|c|}{ Test Value $=2$} \\
\hline & \multirow[b]{2}{*}{$\mathrm{T}$} & \multirow[b]{2}{*}{ df } & \multirow[b]{2}{*}{ Sig. (2-tailed) } & \multirow[b]{2}{*}{ Mean Difference } & \multicolumn{2}{|c|}{$\begin{array}{l}95 \% \text { Confidence Interval of } \\
\text { the Difference }\end{array}$} \\
\hline & & & & & Lower & Upper \\
\hline $\begin{array}{l}\text { Capacity of Local } \\
\text { Governments }\end{array}$ & -168.304 & 899 & .000 & -1.66000 & -1.6794 & -1.6406 \\
\hline
\end{tabular}

Tables 1 and 2 show the results on data obtained on the variable Effectiveness and Development-focus. Table 1 is summary statistics on Effectiveness and Development-focus, Mean $=1.3400$. This shows that respondents tend toward Disagree or Strongly Disagree in their perception of the capacity of local government administration system to be effective and development-focused in Cross River State.

Table 2 shows the result on One-sample T-test carried out on Effectiveness and Development-focus.

Decision Rule: When Test Statistic $\mathrm{T}$ is greater than tabulated statistic t, reject $\mathrm{H}_{0}$ and accept $\mathrm{H}_{\mathrm{a}}$, but when Test Statistic $T$ is less than tabulated statistic $t$, accept $\mathrm{H}_{0}$ and reject $\mathrm{H}_{\mathrm{a}}$

Test Statistic $T=X-\mu /(s / \sqrt{ } n)$

Where $\mathrm{X}=$ observed mean 


$$
\begin{aligned}
& \mu=\text { population mean } \\
& \mathrm{s}=\text { standard deviation } \\
& \mathrm{n}=\text { number of observations } \\
& =1.240-3 /(0.296 / 30) \\
& =-1.66 / 0.0099 \\
& =-176.53
\end{aligned}
$$

Since Test Statistic T (-176.07) is less than tabulated statistic t $(-167.79)$, we do not have sufficient statistical evidence to reject $\mathrm{H}_{0}$, we therefore accept $\mathrm{H}_{0}$ and conclude that: Involvement by the state government in the affairs of the local governments has significantly undermined the capacity of the local governments to function well.

Table 3: Means/Medium of Interference in Local Government Administration by State Government

\begin{tabular}{|l|l|l|}
\hline Factors & Number of Agreeing Respondents & Percentage (\%) \\
\hline $\begin{array}{l}\text { Interference with budgetary } \\
\text { Allocations }\end{array}$ & 828 & 92 \\
\hline Appointments & 774 & 86 \\
\hline Electoral Fraud & 747 & 83 \\
\hline God-fatherism & 540 & 60 \\
\hline The Constitution itself & 612 & 68 \\
\hline
\end{tabular}

Table 3 above shows the shows the means/medium of interference employed by the State Government in the affairs of Local Governments in Cross River State. It is shown that $828(92 \%)$ respondents considered Interference with budgetary allocations as a means of interference by the State Government, $774(86 \%)$ respondents considered Appointments as a means of interference by the State Government, 747 (83\%) considered Electoral Fraud as a means of interference by the State Government, 540 (60\%) considered Godfatherism as a means of interference by the State Government, while $612(68 \%)$ considered the Constitution itself as giving the State Government the power of interference in the guise of oversight (Section 162, paragraph 3-10).

Discussion

From the findings of this study, we do not have sufficient statistical evidence to reject $\mathrm{H}_{0}$, we therefore accept $\mathrm{H}_{0}$ and conclude that: Involvement by the state government in the affairs of the local governments has significantly undermined the capacity of the local governments to function well. This of course suggests that there is interference by the state government in the affairs of local governments in Cross River State, there is no genuine local autonomy and control which in turn has resulted in the fact that the local governments have not functioned as agents of positive change which the people at the grassroots can perceive and relate with as providing solutions and bringing development. The findings of this study show that the concept of local governance when compared with the reality on ground in Nigeria, as exemplified by Cross River State, is a farce and fallacy. Abutudu (2011) posited that development and good governance are intertwined with the concept of democracy. He suggested that denied of this anchor on a democratic base (development and good governance), the local government system in Nigeria will be invariably suspended from the grassroots. The local councils will hardly be developmental, just as they are practically unaccountable. His views support the findings of this study.

The findings of this study suggest that right at local government administration level, most political office holders and candidates are forced upon the local population by the political elites, and therefore prone to manipulation and predatory tendencies of the state government. Since they are going into the office with such a mindset, it is unfathomable for them to have a change of mindset (i.e. by autonomous and independent) when they get into office, this explains why they cannot be effective and development-focused, after all, that was not their original motive for going into political office. This is a widespread problem among the political class in Nigeria. These views are supported by Thomson (1968) and Tourqville (1969). Government ought to be set up and run if they are to be good government, when the reason for government is aimed for the common good and is wholly supported by all citizens of good will (Thomson, 1968). An ideal state is a very small, compact, more like the tiny Greek states of old. Alexis DeTouqueville (1969) on the other hand was fascinated by the nature of America's democracy and public administration. This arose from his visit to the United State of America (U.S.A.) and the realization that the citizens were very much involved in the management of their government whether at the local, municipal or at the metropolitan levels. This is the missing link in state government-local government relationship in Cross River State (i.e. lack of meaningful local citizen participation in local affairs). In other words, there is a predatory relationship between state government and local governments in Cross River State, and this is exemplified in local government administration as shown by the findings of this study.

The local government administration system is an example of an inherited structure from the colonial powers. Studies have shown that the experience of many African countries with the style of adopting the system 
of government inherited from their colonial masters has often turned out to be a failure, this is often due to the predatory relationship between the center (federal or state governments) and the Local Governments (Green, 1995; Wunsch and Olowu, 1990; Ikeji, 2002; Ikeji, 2006). This view is supported by the findings of this study. This view is corroborated by Olowu and Erero (1997), in their study, they found that the services the local government administrations provide have declined sharply in quality and quantity, which inadvertently has given rise to the development of alternative institutional structures for providing essential services.

\section{Summary and Conclusion}

The local government administration system is the closest level of government to the people at the grassroots. Provision has been made in the Nigerian constitution of 1999 for the functioning of the local government administration system. The local government is supposed to provide a people-oriented development focus. However, since the inception of the present democratic dispensation in Nigeria in 1999, getting the local government councils to function as development and positive change agent for communities and residents has been a challenge. These views are supported by the findings of this study and those of others (Olowu and Erero 1997; Green, 1995; Wunsch and Olowu, 1990; Abutudu, 2011; Mukoro, 2009).

However, it is obvious that the local government system cannot be scrapped as it remains the closest level of government to the grassroots. As suggested by King (1988), Ikelegba (2005) and Mukoro (2009), this arm of government is essential to the people, and therefore should be strengthened. The local government administration system remains the panacea to the frustrating experience with highly centralized national governments. This view is supported by this researcher. Therefore the local government administration system though has its problems, and are generally designated as ineffective and not meeting the development needs of the people as shown by the findings of this study, their peculiar problems can be investigated, and ways found to mitigate them.

Conclusions reached in this study are as follows:

There is undue interference by the State Government in the affairs of the Local Governments in Cross River State

The net effect of this undue interference is the undermining the ability of Local Government to function well; and

For all practical purposes, Local Governments qua Local Governments scarcely exist in Cross river State beyond names.

\section{Recommendation}

While the local government administration system in Cross River State is generally considered to be inept, ineffective, and non-development-focused, the findings of this study show that undue interference in the affairs of the Local Governments by the State Governments in large measure accounts for this situation.

The local government system should be strengthened by being made to function as a government indeed with autonomy and control over their resources without undue involvement and interference of the state government. Local government administrations must have levels of autonomy which is commensurate with its functions, local peculiarities and democratic credibility. As the closest governmental authority to the people, it should have the necessary powers to function and control its own finances and personnel. This autonomy and powers should be subject to investigation, probe or scrutiny where necessary, to ensure they are used indeed for achieving development for their constituencies.

Every local government community and their people should imbibe the culture of electing into offices morally sound people and people who have a record of competence in managing resources and achieving success that is measurable. This is their first precaution towards avoiding a disloyal, non-representative and ineffective and non-development focused local government administration. Elections as the chief tool to midwife a democracy also implies that those given the mandate to govern must view that mandate in terms of the imperative of promoting the welfare of the electorate.

\section{References}

Abutudu M. (2011) The Challenges and Opportunities for Improving the Local Government System in Nigeria.Paper Prepared for Presentation at the Third Biennial National Conference on Community Development in Nigeria Held at Grand Hotel, Asaba, November, 20-24, 2011.

Abutudu, Musa (2011) Popular Participatory Approach, Good Governance and Constituency Management. Paper Prepared for Presentation at the Capacity Building Induction for OsunState House of Assembly Legislators, held in Accra, Ghana from June26-30, 2011.

Ayee J (1996). 'Intergovernmental Relations in Ghana, 1988-1995'in Third International Conference of the International Institution of Administrative Sciences. Beijing, China. 
Bello-Imam IB, Obadan IM (2004).'Democratic Governance and Development Management in Nigeria's 4th Republic, 1999-2003.ThePrologue’. In Bello-Imam, I.B. and Obadan M.I. (ed.). DemocraticGovernance and Development Management in Nigeria's Fourth Republic 1999-2003. Ibadan, Centre for Local Government and Rural Development Studies (CLGARDS).

DiMaggio, P. J. (1983).State expansion and the structuration of organizational fields. In Organizational Theory and Public Policy,ed. R. Hall, R. Quinn. Beverly Hills:Sage.

Esman M (1991). Management Dimensions of Development: Perspectives and Strategies. Kumarian press: West Hartford, Lonn.

Federal Republic of Nigeria (2005).National Political Reform Conference Report of the Committee on Public Service.

Federal Republic of Nigeria (2005).National Political ReformConference Report of the Committee on the Executive.

Gboyega A (2003). Democracy and Development. The Imperative of Local Good Governance. Ibadan, Vantage Publishers Ltd.

Green D (1995). Decentralized Public Service Provision in Sub-Saharan Africa: A False Start.Burlington, VC Associates in Rural Development.

Ikeji C. C. (2002). Local Government and Governance in Nigeria: Issues and Ecological Problems. Global Journal of Social Sciences, Vol 1(1), pp 45-49.

Ikeji C. C. (2006). Democratic Institutions and the Challenge of Change Management at the Local Government Level in Nigeria. Journal of Policy and Administrative Studies, Vol 2(1), December 2006.

Ikelegba, A. O. (2005) "The Local Government System and Grassroots Development in Nigeria: Issues, Problems and Challenges", in Onokerhoraye, Andrew G. and Omuta, Gideon, E.D., Perspectives on Development: A Book in Honour of Pius Oghenerukohwo Sada. Benin City: Centre for Population and Environmental Development. pp 37-63.

Ikelegbe, A. O. (2005) "The Local Government System and Grassroots Development in Nigeria: Issues, Problems and Challenges", in Onokerhoraye, Andrew G. and Omuta, Gideon, E.D., Perspectives on Development: A Book in Honour of Pius OghenerukohwoSada. Benin City: Centre for Population and Environmental Development. pp 37-63.

Johnston A (1998). 'On Developing Institutions in Africa' in WohlgemuthLennart, Carisson Jerker, KifleHenock (ed) Institution Building and Leadership in Africa. Uppsala, Nordiska Afrika institutet.

King, Mae C.(1988) Localism and Nation Building . Ibadan: Spectrum Books.

Kolawole, D. (2006). A Paper delivered at the event marking the Local Government day in Ondo state, Nigeria. May 26.

Meyer, J. W., Rowan, B. (1977). Intitutionalized organizations: Formal structure as myth and ceremony. Am. 1.Sociol.83:340-63

Mukoro A. (2009). Building institutions for partnership in local governance in Nigeria. International NGO Journal Vol. 4 (5), pp. 216-224, May, 2009. Available online at http:// www.academicjournals.org/INGOJ

Mutahaba G (1989). Reforming Public Administration for development: Experiences from Eastern Africa.Wist Hartford, Conn, Kumarian Press.

Nkwocah, Jeff (2009) Non Conduct of LG elections in Anambra State", Thisday (online) August6.

Okafor, Jude (2010) 'Local Government Financial Autonomy in Nigeria: The Sate Joint Local Government Account”. Commonwealth Journal of Local Governance. Issue 6, July.127-131.

Olowu D (1995). 'The Failure of Current Decentralization Programmes in Africa'. In James Wunsch and Olowu Dele (ed.) The Failure of the Centralized State: Institutions and Self Governance in Africa. California, I.C.S. Press.

Olowu D (2002). 'Governance in Developing Countries; the Challenge of Multi-level Governance.' The Geospatial Resource Portal (GIS Development) www.Gisdevelopment.net

Olowu D and Smoke P (eds) (1992). Special Issue: Successful African Local Government: Public Administration and Development 12 (1): 1-122.

Olowu D, Erero J (1997). Introduction: Governance of Nigeria's Villages and Cities through Indigenous Institutions in Olowu Dele and Erero John 'Indigenous Governance Systems in Nigeria. Ile-Ife, L.I.S.D.P.

Olowu D, Wunsch J (1995). 'Decentralization, Local Government and Primary Health Care in Nigeria: An Analytical Study' in J. Afr. Pol. Stud. 1: No. 3.

Olowu D. (2001). African Decentralization Policies and Practices from 1980s and Beyond. Working Papers (no. 334), Institute of Social Studies, The Hague.

Perrow , C. (1986). Complex Organizations: A Critical Essay. New York: Random. $3^{\text {rd }}$ ed. 
Scott, W. R . , Meyer, J. W. 1983. The organization of societal sectors . See Meyer \&Scott 1 983, pp. $129-53$

Sehinde, B. (2008). Need for a Review of Statutory Roles of Local Government for Effective Service. In: Journal of contemporary Politics, (1), University of Ado-Ekiti, 102.

Selznick, P. 1949. TVA and the Grass Roots. Berkeley: Univ. Calif. Press

Selznick, P. 1957. Leadership in Administration: A Sociological Interpretation. Evanston, Ill: Row, Peterson.

Skelcher C (2005). 'Jurisdictional Integrity, Polycentrism, and the Design of Democratic overnance' in Governance (An Inter. J. Pol., Admin. Institutions) 18: 1.

Thomas, G .M . , Meyer, J. W., Ramirez, F. ,Boli, J. 1987. Institutional Structure: Constituting State, Society, and the Individual. Newbury Park, Calif: Sage. In press.

Thomas, G. M . , Meyer, J. W. 1984. The expansion of the state. Ann. Rev. Sociol.10:461-82

Thomson D (1968). 'Rousseau and the General Will' in Thomson David (ed) Political Ideas. England, Penguin Books.

Tocqueville A. (1966). Democracy in America (JP Mayer edn). Doubleday: Garden City, NJ.

Tocqueville de A (1969).Democracy in America. Translated by George Lawrence and edited by J.P. Mayer. New York, Anchor Books.

Weick, K. E. 1976. Educational organizations as loosely coupled systems. Admin. Sci. Q.21: 1-19.

Wunsch J. S. (2001). Decentralization, Local Governance and 'Recentralization' in Africa.Public Administration and Development 21, 277-288, John Wiley and Sons Ltd (2001).

Wunsch S. J. (2004). "Decentralization, Local Governance and theDemocratic Transition in Southern Africa: A Comparative Analysis"in African Studies Quarterly.The online J. for Afr. Stud.

Wunsch J., and Olowu D. (1990). The Failure of the Centralized State: Institutions and Self Governance in Africa. Westview Press: Boulder,Co.

Wunsh J, Olowu D (1996). 'Regime Transformation from Below: Decentralization, Local Governance and democratic reforms inNigeria' in Studies in Comparative International Development.Boulder, Co.

Zucker, L. G. 1977. The role of institutionalization in cultural persistence. Am. Sociol. Rev. 42:726-43. 
This academic article was published by The International Institute for Science, Technology and Education (IISTE). The IISTE is a pioneer in the Open Access Publishing service based in the U.S. and Europe. The aim of the institute is Accelerating Global Knowledge Sharing.

More information about the publisher can be found in the IISTE's homepage: http://www.iiste.org

\section{CALL FOR JOURNAL PAPERS}

The IISTE is currently hosting more than 30 peer-reviewed academic journals and collaborating with academic institutions around the world. There's no deadline for submission. Prospective authors of IISTE journals can find the submission instruction on the following page: http://www.iiste.org/journals/ The IISTE editorial team promises to the review and publish all the qualified submissions in a fast manner. All the journals articles are available online to the readers all over the world without financial, legal, or technical barriers other than those inseparable from gaining access to the internet itself. Printed version of the journals is also available upon request of readers and authors.

\section{MORE RESOURCES}

Book publication information: http://www.iiste.org/book/

Recent conferences: http://www.iiste.org/conference/

\section{IISTE Knowledge Sharing Partners}

EBSCO, Index Copernicus, Ulrich's Periodicals Directory, JournalTOCS, PKP Open Archives Harvester, Bielefeld Academic Search Engine, Elektronische Zeitschriftenbibliothek EZB, Open J-Gate, OCLC WorldCat, Universe Digtial Library, NewJour, Google Scholar

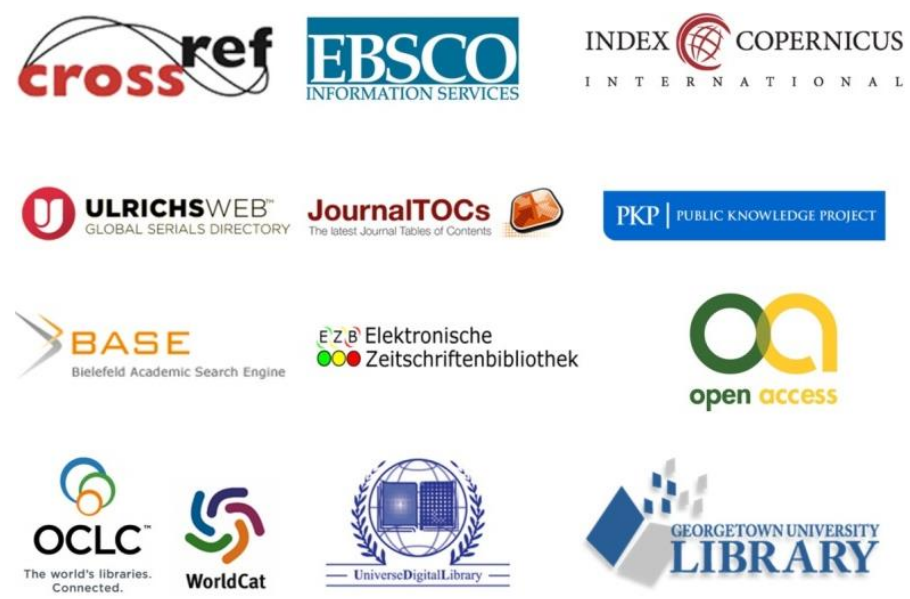

